\title{
Pyranicin, a non-classical annonaceous acetogenin, is a potent inhibitor of DNA polymerase, topoisomerase and human cancer cell growth
}

\author{
SHUNYA TAKAHASHI ${ }^{1 *}$, YUKO YONEZAWA ${ }^{2 *}$, AKEMI KUBOTA $^{1}$, NARIHITO OGAWA $^{1}$, \\ KATSUYA MAEDA ${ }^{1}$, HIROYUKI KOSHINO ${ }^{1}$, TADASHI NAKATA ${ }^{4}$, \\ HIROMI YOSHIDA ${ }^{2,3}$ and YOSHIYUKI MIZUSHINA ${ }^{2,3}$ \\ ${ }^{1}$ RIKEN (The Institute of Physical and Chemical Research), Wako-shi, Saitama, 351-0198; \\ ${ }^{2}$ Laboratory of Food \& Nutritional Sciences, Department of Nutritional Science, and ${ }^{3}$ Cooperative Research Center \\ of Life Sciences, Kobe-Gakuin University, Nishi-ku, Kobe, Hyogo 651-2180; ${ }^{4}$ Department of Chemistry, \\ Faculty of Science, Tokyo University of Science, Kagurazaka, Shinjuku-Ku, Tokyo 162-8601, Japan
}

Received August 27, 2007; Accepted October 25, 2007

\begin{abstract}
This report describes the inhibitory activities of the natural and non-natural acetogenins [mucocin (compound 1), jimenezin (compound 2), 19-epi jimenezin (compound 3), muconin (compound 4), pyranicin (compound 5), pyragonicin (compound 6), 10-epi pyragonicin (compound 7), and a $\gamma$-lactone (compound 8)], which were synthesized by us, against DNA polymerase (pol), DNA topoisomerase (topo), and human cancer cell growth. Among the compounds tested, compound 5 was revealed to be the strongest inhibitor of the animal pols and human topos tested, and the $\mathrm{IC}_{50}$ values for pols and topos were 2.3-15.8 and 5.0-7.5 $\mu \mathrm{M}$, respectively. The compound also suppressed human cancer cell (promyelocytic leukemia cell line, HL-60) growth with the same tendency as the inhibition of pols and topos and
\end{abstract}

Correspondence to: Dr Yoshiyuki Mizushina, Laboratory of Food \& Nutritional Sciences, Department of Nutritional Science, Kobe-Gakuin University, Nishi-ku, Kobe, Hyogo 651-2180, Japan E-mail:mizushin@nutr.kobegakuin.ac.jp

${ }^{*}$ Contributed equally

Abbreviations: pol, DNA-directed DNA polymerase (E.C. 2.7.7.7); topo, DNA topoisomerase; THF, tetrahydrofuran; THP, tetrahydropyran; dNTP, 2'-deoxyribonucleotide 5'-triphosphate; dTTP, 2'-deoxythymidine 5'-triphosphate; TdT, terminal deoxynucleotidyl transferase; DMSO, dimethyl sulfoxide; $\mathrm{IC}_{50}, 50 \%$ inhibitory concentration; $\mathrm{LD}_{50}, 50 \%$ lethal dose; dsDNA, doublestranded DNA

Key words: acetogenins, pyranicin, enzyme inhibitor, DNA polymerase, DNA topoisomerase, cytotoxicity, cell proliferation, cell cycle arrest, apoptosis the $\mathrm{LD}_{50}$ value was $9.4 \mu \mathrm{M}$. Compound 5 arrested the cells at $\mathrm{G} 2 / \mathrm{M}$ and $\mathrm{G} 1$ phases, and prevented the incorporation of thymidine into the cells, indicating that it blocks DNA replication by inhibiting the activity of pols and topos. This compound also induced apoptosis of the cells. Based on these results, the action mode of compound 5 is discussed.

\section{Introduction}

DNA polymerase (pol) catalyzes the addition of deoxyribonucleotides to the 3'-hydroxyl-terminus of primed doublestranded DNA molecules (1). The human genome encodes 14 pols which conduct cellular DNA synthesis (2). Eukaryotic cells reportedly contain three replicative types: pols $\alpha, \delta$ and $\varepsilon$ mitochondrial pol $\gamma$, and at least twelve repair types: pols $\beta$, $\delta, \varepsilon, \zeta, \eta, \theta, \iota, \kappa, \lambda, \mu$ and $\sigma$ and REV1 (3).

DNA topoisomerases (topos) are key enzymes that control the topological state of DNA. There are two classes of topos: type I enzymes, which act by transiently nicking one of the two DNA strands, and type II enzymes, which nick both DNA strands and dependent on ATP, are involved in many vital cellular processes that influence DNA replication, transcription, recombination, integration and chromosomal segregation (4).

DNA metabolic enzymes such as pols and topos are not only essential for DNA replication, repair and recombination, but are also involved in cell division. Selective inhibitors of these enzymes are considered as a group of potentially useful anti-cancer and anti-parasitic agents, because some inhibitors suppress human cancer cell proliferation and have cytotoxicity (5-8).

Acetogenins from Annonaceae species are a relatively new class of fatty acid-derived natural products that have a wide range of biological activities such as cytotoxic, antitumor and immunosuppressive effects (9-11). They are characterized by the presence of one to three tetrahydrofuran (THF) rings in the center of a long alkyl chain with a 
butenolide moiety at the end. Besides such classical types, acetogenins with a tetrahydropyran (THP) ring in the long chain such as mucocin (compound 1), jimenezin (compound 2), muconin (compound 4), pyranicin (compound 5), and pyragonicin (compound 6) have also been discovered (12-15). Recently, we have been interested in the non-classical THP acetogenins because of the powerful antitumor activity, and achieved total synthesis of the natural and non-natural acetogenins (compounds 1-8) (16-24). In connection with our studies on a search for new pol and topo inhibitors and development of new anticancer drugs, we initiated biological studies of these acetogenins. Since the groups of McLaughlin and Mata reported that some acetogenins have cytotoxicity to human cancer cell lines (12-15), the purpose of our studies is to investigate the biochemical action of the compounds in detail and to use the compound as an anti-neoplastic agent.

Herein, we describe the inhibitory activities of chemically synthesized acetogenins against pols, topos and other DNA metabolic enzymes, and cellular proliferation processes such as DNA replication of human cancer cells (HL-60). It was discussed that acetogenins seem to be an ideal model for the development of new anti-cancer drugs.

\section{Materials and methods}

Materials. Eight chemically synthesized acetogenins (i.e., compounds 1-8; Fig. 1) were employed (16-24). Nucleotides and chemically synthesized DNA template-primers, such as poly $(\mathrm{dA})$, poly $(\mathrm{rA})$, and oligo(dT) $)_{12-18}$, and radioisotope reagents, such as $\left[{ }^{3} \mathrm{H}\right]$-dTTP $\left(2^{\prime}\right.$-deoxythymidine 5'-triphosphate) (43 Ci/mmol), [methyl- $\left.{ }^{3} \mathrm{H}\right]$-thymidine, $\left[5,6-{ }^{3} \mathrm{H}\right]$ uridine and $\mathrm{L}-\left[4,5-{ }^{3} \mathrm{H}\right]$-leucine, were purchased from GE Healthcare Bio-Science Corp. (Buckinghamshire, UK). All other reagents were of analytical grade and were purchased from Nacalai Tesque, Ltd. (Kyoto, Japan). HL-60, a human promyelocytic leukemia cell line (IFO 050022), was supplied by the Health Science Research Resources Bank (Osaka, Japan).

Enzymes. Pol $\alpha$ was purified from the calf thymus by immunoaffinity column chromatography as described by Tamai et al (25). Recombinant rat pol $\beta$ was purified from E. coli JMpß5 as described by Date et al (26). The human pol $\gamma$ catalytic gene was cloned into pFastBac, and histidine-tagged enzyme was expressed using the BAC-TO-BAC HT Baculovirus Expression System according to the supplier's manual (Life Technologies, MD, USA) and purified using ProBoundresin (Invitrogen, Tokyo, Japan) (27). Human pols $\delta$, and $\varepsilon$ were purified by the nuclear fractionation of human peripheral blood cancer cells (Molt-4) using the second subunit of pols $\delta$ and $\varepsilon$-conjugated affinity column chroma-tography, respectively (28). Recombinant human pols $\eta$ and $\iota$ tagged with His6 at their C-terminal were expressed in SF9 insect cells using the Baculovirus Expression System, and were purified as described previously $(29,30)$. A truncated form of pol $\kappa$ (i.e., hDINB1DC) with 6X His-tags attached at the Cterminal was overproduced using the BAC-to-BAC Baculovirus Expression System kit (Gibco-BRL) and purified as described by Ohashi et al (31). Recombinant human Hispol $\lambda$ was overexpressed and purified according to a method
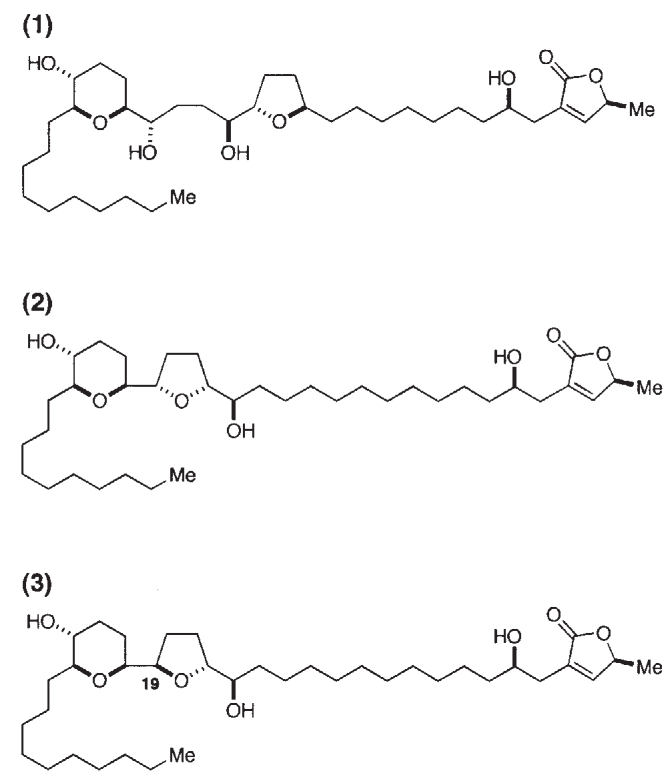

(4)

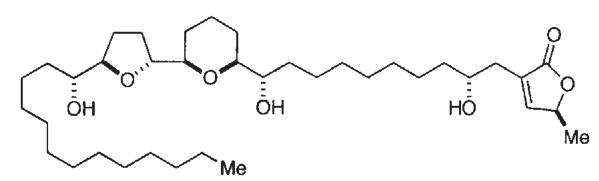

(5)

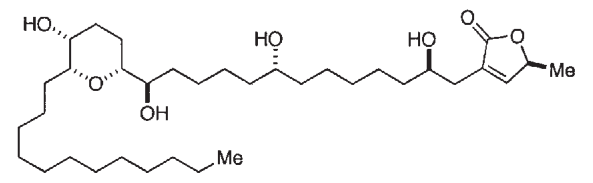

(6)

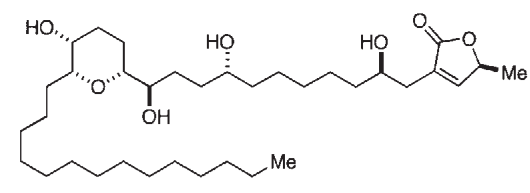

(7)

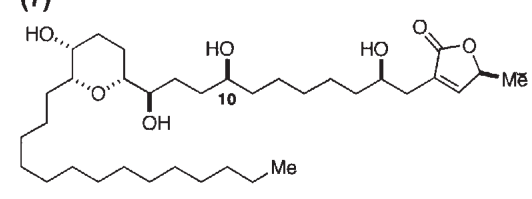

(8)

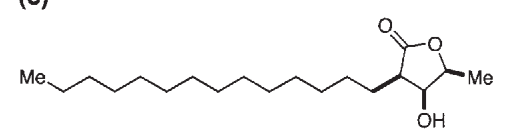

Figure 1. Chemical structures of acetogenins. (1) Compound 1, mucocin; (2) compound 2, jimenezin; (3) compound 3, 19-epi jimenezin; (4) compound 4, muconin; (5) compound 5, pyranicin; (6) compound 6, pyragonicin; (7) compound 7, 10-epi pyragonicin; and (8) compound 8, 3-hydroxy-4-methyl2-tetradecyl-4-butanolide.

described by Shimazaki et al (32). Fish pol $\delta$ was purified from the testis of cherry salmon (Oncorhynchus masou) (33). 
Fruit fly pols $\alpha, \delta$, and $\varepsilon$ were purified from early embryos of Drosophila melanogaster as described by Aoyagi et al $(34,35)$. Pols I ( $\alpha$-like) and II ( $($-like) from a higher plant, cauliflower inflorescence, were purified according to the methods outlined by Sakaguchi et al (36). Calf thymus terminal deoxynucleotidyl transferase (TdT) and bovine pancreas deoxyribonuclease I were obtained from Stratagene Cloning Systems (La Jolla, CA, USA). The Klenow fragment of pol I from $E$. coli was purchased from Worthington Biochemical Corp. (Freehold, NJ, USA). Taq pol, T4 pol, T7 RNA polymerase and T4 polynucleotide kinase were purchased from Takara (Kyoto, Japan). Purified human placenta topos I and II were purchased from TopoGen, Inc. (Columbus, $\mathrm{OH}$ ).

DNA polymerase assays. The reaction mixtures for pol $\alpha$, pol $\beta$, plant pols and prokaryotic pols were described previously $(37,38)$, and those for pol $\gamma$, and pols $\delta$ and $\varepsilon$ were as described by Umeda et al (27) and Ogawa et al (39), respectively. The reaction mixtures for pols $\eta, \iota$ and $\kappa$ were the same as that for pol $\alpha$, and the reaction mixture for pol $\lambda$ was the same as that for pol $\beta$. For pols, poly $(\mathrm{dA}) /$ oligo $(\mathrm{dT})_{12-18}(\mathrm{~A} / \mathrm{T}=2 / 1)$ and dTTP were used as the DNA template-primer and nucleotide (i.e., 2'-deoxyribonucleotide 5'-triphosphates, dNTP) substrate, respectively. For TdT, oligo $(\mathrm{dT})_{12-18}\left(3^{\prime}-\mathrm{OH}\right)$ and dTTP were used as the DNA template-primer and nucleotide substrate, respectively.

Chemically synthesized acetogenins were dissolved in dimethyl sulfoxide (DMSO) at various concentrations and sonicated for $30 \mathrm{sec}$. Aliquots of $4 \mu \mathrm{l}$ of sonicated samples were mixed with $16 \mu 1$ of each enzyme (final amount 0.05 units) in $50 \mathrm{mM}$ Tris- $\mathrm{HCl}(\mathrm{pH} 7.5)$ containing $1 \mathrm{mM}$ dithiothreitol, 50\% glycerol and $0.1 \mathrm{mM}$ EDTA and kept at $0^{\circ} \mathrm{C}$ for $10 \mathrm{~min}$. These inhibitor-enzyme mixtures $(8 \mu \mathrm{l})$ were added to $16 \mu$ l of each of the enzyme standard reaction mixtures and incubation was carried out at $37^{\circ} \mathrm{C}$ for $60 \mathrm{~min}$, except for $\mathrm{Taq}$ pol, which was incubated at $74^{\circ} \mathrm{C}$ for $60 \mathrm{~min}$. Activity without the inhibitor was considered $100 \%$, and the remaining activity at each concentration of the inhibitor was determined relative to this value. One unit of pol activity was defined as the amount of enzyme that catalyzed the incorporation of $1 \mathrm{nmol}$ of dNTP (i.e., dTTP) into synthetic DNA template-primers in $60 \mathrm{~min}$ at $37^{\circ} \mathrm{C}$ under the normal reaction conditions for each enzyme $(37,38)$.

Other enzyme assays. The primase activity of pol $\alpha$ the activities of T7 RNA polymerase, human topos I and II, T4 polynucleotide kinase and bovine deoxyribonuclease I were measured in standard assays according to the manufacturer's specifications as described by Tamiya-Koizumi et al (40), Nakayama et al (41), Spitzner et al (42), Soltis et al (43) and Lu and Sakaguchi (44), respectively.

Investigation of cytotoxicity on cultured cells. To investigate the effects of acetogenins (i.e., compounds 1-8) on cultured cells, a human cancer cell line HL-60, derived from a cancer patient, was used. The cells were routinely cultured in RPMI1640 medium supplemented with $10 \%$ fetal bovine serum, $100 \mu \mathrm{g} / \mathrm{ml}$ streptomycin, $100 \mathrm{unit} / \mathrm{ml}$ penicillin and $1.6 \mu \mathrm{g} / \mathrm{ml}$ $\mathrm{NaHCO}_{3}$. The cells were cultured at $37^{\circ} \mathrm{C}$ in standard medium in a humidified atmosphere of $5 \% \mathrm{CO}_{2}-95 \%$ air. The cytotoxicity of the compound was investigated as follows. High concentrations $(10 \mathrm{mM})$ of the compounds were dissolved in DMSO and stocked. Approximately $1 \times 10^{4}$ cells per well were inoculated in 96-well micro-plates, and then the compound stock solution was diluted to various concentrations and applied to each well. After incubation for $24 \mathrm{~h}$, the survival rate was determined by MTT (3-(4,5dimethylthiazol-2-yl)-2,5-diphenyl tetrazolium bromide) assay (45).

Cell cycle analysis. Cellular DNA content for cell cycle analysis was determined as follows: aliquots of $3 \times 10^{5}$ HL-60 cells were harvested into a $35-\mathrm{mm}$ dish, and incubated with medium containing compound 5 for various times. The cells were then washed with ice-cold PBS three times by centrifugation, fixed with $70 \%(\mathrm{v} / \mathrm{v})$ ethanol and stored at $-20^{\circ} \mathrm{C}$. DNA was stained with DAPI staining solution for at least $10 \mathrm{~min}$ at room temperature in the dark. Fluorescence intensity was measured by FACSCanto flow cytometer in combination with FACSDiVa software (BD, BectonDickinson and Company, NJ, USA).

Measurement of inhibition of synthesis of DNA, RNA and protein. The effect of compound 5 on DNA, RNA and protein synthesis was examined independently. HL-60 cells $\left(1 \times 10^{4}\right)$ were inoculated into 96-well micro-plates and preincubated without the compound for several hours. Medium containing compound 5 diluted with 0.5\% DMSO solution was then applied to the cells, and this time point was taken as $0 \mathrm{~h}$. At $-0.5 \mathrm{~h}$, as probes for DNA, RNA or protein synthesis, [methyl- $\left.{ }^{3} \mathrm{H}\right]$-thymidine, $\left[5,6-{ }^{3} \mathrm{H}\right]$-uridine or $\mathrm{L}-\left[4,5-{ }^{3} \mathrm{H}\right]$-leucine (final concentration, 3,4 and $4 \mu \mathrm{Ci}$, respectively) was added. At specified time points, incubation was stopped and cell lysate was prepared to measure the incorporated radioactivity as described for the cytotoxicity assay.

Analysis of DNA fragmentation. Apoptosis was determined by an assay of DNA fragmentation by means of agarose electrophoresis. Total DNAs were extracted from $6 \times 10^{5}$ HL-60 cells, following the method of Sambrook et al (46), and $5 \mu \mathrm{g}$ aliquots were separated by $1.5 \%(\mathrm{w} / \mathrm{v})$ agarose gel electrophoresis in $40 \mathrm{mM}$ Tris $-5 \mathrm{mM}$ sodium acetate - $1 \mathrm{mM}$ EDTA (pH 7.8) and stained with ethidium bromide. DNA bands were visualized under UV light.

\section{Results}

Effects of acetogenins on mammalian DNA polymerases $\alpha, \beta$ and $\lambda$. The chemical structures of the acetogenins (i.e., compounds 1-8), which were chemically synthesized, are shown in Fig. 1. First, the inhibitory activity of calf pol $\alpha$, rat pol $B$ and human pol $\lambda$ against $10 \mu \mathrm{M}$ of each compound was investigated (Fig. 2A). In mammalian pols, pol $\alpha$ and pols $\beta$ and $\lambda$ were used as representative replicative pol and repair/ recombination-related pols, respectively $(2,3)$. Compounds 5 and 6 significantly inhibited the activities of these pols, and in order of their effect, the acetogenins ranked as follows: compound $5>$ compound $6>$ compound $7>$ compound $4>$ 
$\mathbf{A}$

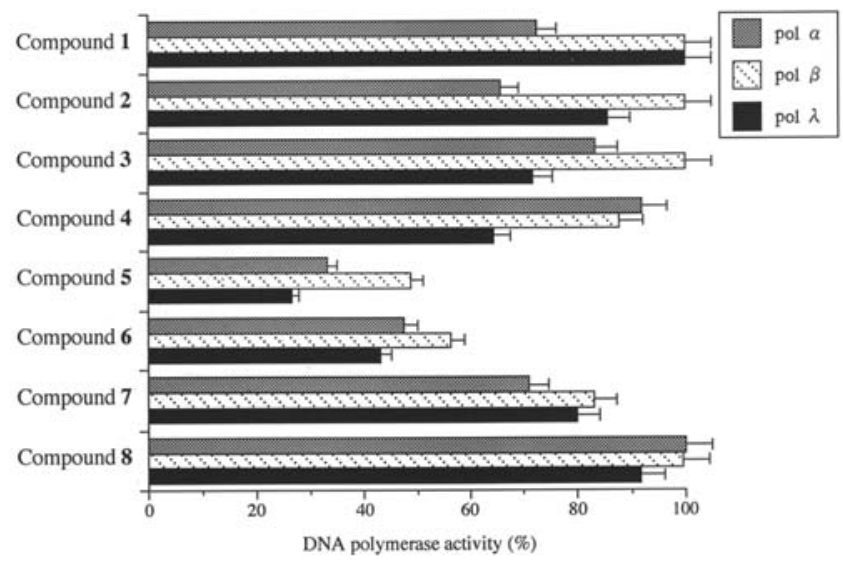

B

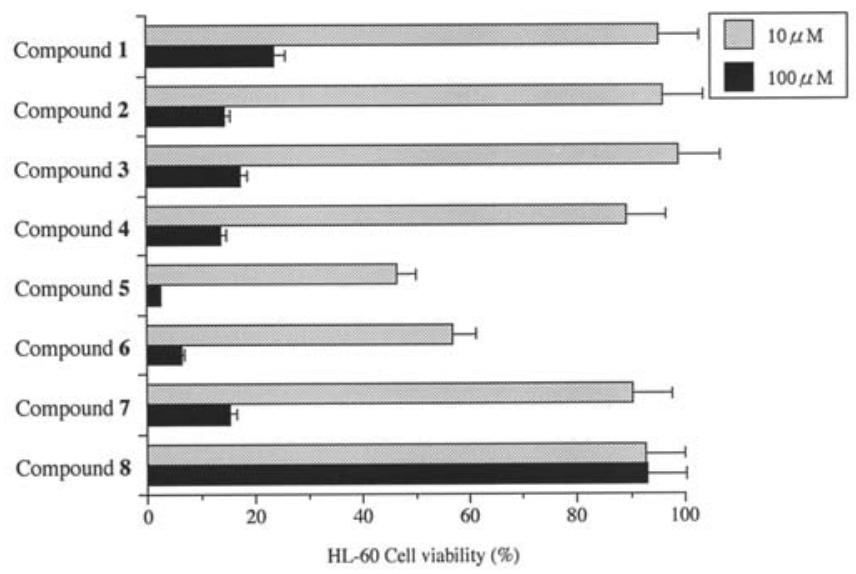

Figure 2. Effect of acetogenins on the activities of mammalian pols and human cancer cell growth. (A) Ten $\mu \mathrm{M}$ of each compound was incubated with calf pol $\alpha$, rat pol $\beta$ and human pol $\lambda$ (0.05 units each). Pol activities were measured as described in Materials and methods. Enzymatic activity in the absence of the compound was taken as $100 \%$. Data are shown as the mean \pm SEM of three independent experiments. (B) Each compound (10 and $100 \mu \mathrm{M}$ ) was added to the culture of a promyelocytic leukemia cell line HL-60 and incubated for $24 \mathrm{~h}$. The rate of viability was determined by MTT assay (45). Cell viability of the cancer cells in the absence of the compound was taken as $100 \%$. Data are shown as the mean \pm SEM of five independent experiments.

compound $3>$ compound $2>$ compound $1>$ compound 8 . Compound 5 showed the strongest inhibition of pols $\alpha, \beta$ and $\lambda$ activities in the tested compounds, and $50 \%$ inhibition was observed at doses of 5.3, 9.6 and $2.3 \mu \mathrm{M}$, respectively (Table I). When activated DNA (i.e., DNA digested by bovine deoxynuclease I) was used as the DNA templateprimer instead of poly $(\mathrm{dA}) /$ oligo $(\mathrm{dT})_{12-18}(\mathrm{~A} / \mathrm{T}=2 / 1)$, the mode of inhibition by these compounds did not change (data not shown).

Effects of compounds 5 on DNA polymerases and other DNA metabolic enzymes. Compound 5 also inhibited the activities of other mammalian pols tested (i.e., pols $\gamma, \delta, \varepsilon, \eta, \iota, \kappa$, and $\mathrm{TdT}$ ) with $\mathrm{IC}_{50}$ value of 5.9-15.8 $\mu \mathrm{M}$ (Table I). The pol $\lambda$ inhibitory effect of compound 5 was the strongest in mammalian pols. Furthermore, this compound inhibited animal pols from fish (cherry salmon) pol $\delta$, and insects (fruit fly) pols $\alpha, \delta$ and $\varepsilon$ at almost the same concentration as the
Table I. $\mathrm{IC}_{50}$ values of compound 5 on the activities of various DNA polymerases and other DNA metabolic enzymes.

Enzyme $\mathrm{IC}_{50}$ value $(\mu \mathrm{M})$

Mammalian DNA polymerases

Calf DNA polymerase $\alpha$

$5.3 \pm 0.4$

Rat DNA polymerase $\beta$

$9.6 \pm 0.8$

Human DNA polymerase $\gamma$

$5.9 \pm 0.4$

Human DNA polymerase $\delta$

$8.4 \pm 0.7$

Human DNA polymerase $\varepsilon$

$15.8 \pm 1.4$

Human DNA polymerase $\eta$

$10.2 \pm 0.9$

Human DNA polymerase ı

$13.0 \pm 1.2$

Human DNA polymerase $\kappa$

$11.1 \pm 1.0$

Human DNA polymerase $\lambda$

$2.3 \pm 0.2$

Calf terminal deoxynucleotidyl transferase

$6.3 \pm 0.5$

Fish DNA polymerases

Cherry salmon DNA polymerase $\delta$

$8.8 \pm 0.7$

Insect DNA polymerases

Fruit fly DNA polymerase $\alpha$

$6.5 \pm 0.5$

Fruit fly DNA polymerase $\delta$

$8.9 \pm 0.8$

Fruit fly DNA polymerase $\varepsilon$

$14.0 \pm 1.3$

Plant DNA polymerases

Cauliflower DNA polymerase I ( $\alpha$-like)

Cauliflower DNA polymerase II (ß-like)

$>200$

Prokaryotic DNA polymerases

E. coli DNA polymerase I (Klenow fragment) $\quad>200$

Taq DNA polymerase

$>200$

T4 DNA polymerase

$>200$

Other DNA metabolic enzymes

Calf primase of DNA polymerase $\alpha$

T7 RNA polymerase

Human DNA topoisomerase I

Human DNA topoisomerase II

$7.5 \pm 2.0$

T4 polynucleotide kinase

Bovine deoxyribonuclease I

$>200$

Compound 5 was incubated with each enzyme (0.05 units). Enzymatic activity was measured as described in Materials and methods. Enzyme activity in the absence of the compound was taken as $100 \%$. Data are shown as the mean \pm SEM of four independent experiments.

inhibition of mammalian pols. On the other hand, compound 5 had no significant influence on the activities of pols I $(\alpha$-like pol) and II ( $\beta$-like pol) from plants (cauliflower) and prokaryotes such as the Klenow fragment of E. coli pol I, Taq pol and T4 pol.

In the DNA metabolic enzymes tested, compound 5 also inhibited the activities of human topos I and II with $\mathrm{IC}_{50}$ 
value of 5.0 and $7.5 \mu \mathrm{M}$, respectively (Table I). These results suggested that the inhibitory activity of acetogenins between mammalian pols and human topos had the same tendency, although the inhibitory effect on human pol $\lambda$ was approximately 3 -fold stronger than that on human topo II. This compound did not inhibit the activities of the other DNA metabolic enzymes tested, including calf primase of pol $\alpha \mathrm{T} 7$ RNA polymerase, T4 polynucleotide kinase and bovine deoxyribonuclease I.

To determine whether the inhibitor resulted in binding to DNA or the enzyme, the interaction of compound 5 with double-stranded DNA (dsDNA) was investigated based on the thermal transition of dsDNA with or without the compound. The Tm of dsDNA with an excess amount of compound $5(100 \mu \mathrm{M})$ was measured using a spectrophotometer equipped with a thermoelectric cell holder. In the concentration range used, no thermal transition of Tm was observed, whereas ethidium bromide used as a positive control, a typical intercalating compound, produced a clear thermal transition. These observations indicated that compound 5 did not intercalate to DNA as a template-primer, and the compound might directly bind to the enzyme and inhibit its activity.

These results suggested that compound 5 might be a potent and selective inhibitor of animal pols and human topos. We investigated the mechanism of the inhibitory effect of acetogenins including compound 5 on human cancer cells.

Effects of acetogenins on cultured human cancer cells. Pols and topos have recently emerged as important cellular targets for chemical intervention in the development of anti-cancer agents. Acetogenins (i.e., compounds 1-8) could therefore be useful in chemotherapy and we investigated the cytotoxic effect of eight compounds against a human promyelocytic leukemia cell line, HL-60.

As shown in Fig. 2B, 10 and $100 \mu \mathrm{M}$ of compound 5 had the strongest growth inhibitory effect on this cancer cell line in the tested compounds, and compound 6 was the second strongest (i.e., in order of cytotoxicity: compound $5>$ compound $6>$ compound $7>$ compound $4>$ compound $3>$ compound $2>$ compound $1>$ compound 8 ). The suppression of cell growth had the same tendency as the inhibition of mammalian pols among the compounds (Fig. 2A), suggesting that the cause of cancer cell influence might be the activity of pols, including replicative pols and repair/recombination pols. All compounds tested as acetogenins have a butenolide moiety or a $\gamma$-lactone moiety at the end. Compounds 1 to 7 also consist of one or two rings such as a THF ring and/or a THP ring in the center, although compound 8 has no other rings. Since compound 8 also did not influence the activities of the pols tested and HL-60 cells, the moiety of THF and/or THP rings of compounds 1 to 7 might be important for the inhibition of mammalian pols and human cancer cell growth. Furthermore, the molecular length of compounds 1 to 7 was approximately 1.9 -fold longer than that of compound 8 (i.e., 33.63-37.76 $\AA$ and $19.80 \AA$, respectively) (data not show), 33 to $38 \AA$ of molecular length of the compound must be essential for these inhibitory activities.

Therefore, we concentrated our efforts on compound 5 in the latter part of this study. Compound 5 suppressed HL-60

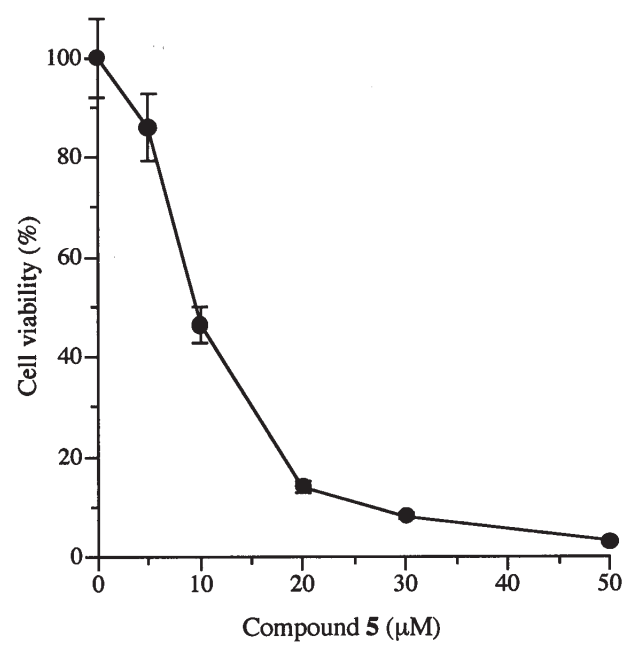

Figure 3. Effect of compound 5 on the proliferation of a human cancer cell line, HL-60. The data show the dose-response curves of growth inhibition of the human promyelocytic leukemia cell line HL-60 incubated with various concentrations of compound 5 for $24 \mathrm{~h}$. Cell proliferation was determined by MTT assay (45). Data are shown as the mean \pm SEM of four independent experiments.

cell growth in a dose-dependent manner. After $24 \mathrm{~h}$ of treatment, $50 \%$ cytotoxicity of this compound was observed at doses of $9.4 \mu \mathrm{M}$ (Fig. 3). This result suggested that the $\mathrm{LD}_{50}$ value in vivo for HL-60 cells was almost the same as the $\mathrm{IC}_{50}$ values in vitro for pols and topos. We investigated in more detail which inhibition by compound 5 is effective for cancer cell proliferation, that of pols or topos.

Effects on the cell cycle progression of compound 5. Next, we analyzed whether compound 5 affected the cell cycle distribution of compound 5-treated cells (Fig. 4). The cell cycle fraction was recorded after 12 and $24 \mathrm{~h}$ of treatment with the $\mathrm{LD}_{50}$ value of the compound (i.e., 9.4 $\mu \mathrm{M}$ ). Consequently, among cells treated with compound 5 for $12 \mathrm{~h}$, the population of cells in the G2/M phase increased (9.6 to $15.2 \%$ ), the percentage of cells in the $\mathrm{S}$ phase decreased from 42.1 to $34.5 \%$, and the G1 phase was not affected (Fig. 4B). These results suggested that the actions of compound 5 blocked the G2/M phase in HL-60 cells by inhibition of topos I and II. For 24-h treatment of compound 5 , the population of cells in the G1 phase significantly increased from 48.3 to $75.6 \%$, and the $\mathrm{S}$ phase decreased (42.1 to $13.1 \%$ ) (Fig. 4C). Dehydroaltenusin, which is a specific pol $\alpha$ inhibitor, inhibited the cell cycle in the G1 phase including the early-S phase (47), and classical topo inhibitors such as etoposide arrested the cell cycle at the G2/M phase (48). Compound 5, therefore, might be more effective in the inhibition of pols than topos for 24-h incubation of cells, although compound 5 inhibited the activities of mammalian pols and human topos, and the inhibitory effect for topos ( $\mathrm{IC}_{50}$ values are 5.0-7.5 $\mu \mathrm{M}$ ) was the almost same as that for pols $\left(\mathrm{IC}_{50}\right.$ values are 2.3-15.8 $\left.\mu \mathrm{M}\right)$ in vitro (Table I).

Effects of inhibition of synthesis of DNA, RNA and protein by compound 5 in human cancer cells. The results of cell 
$\mathbf{A}$

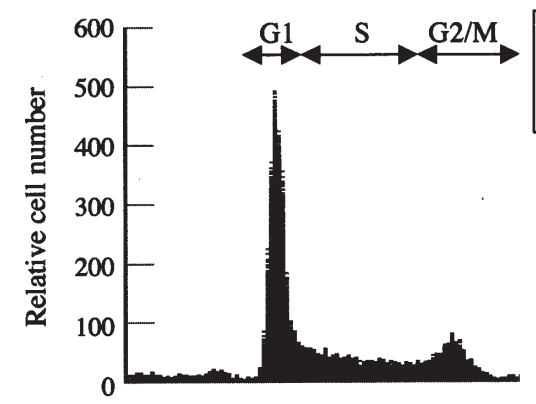

B

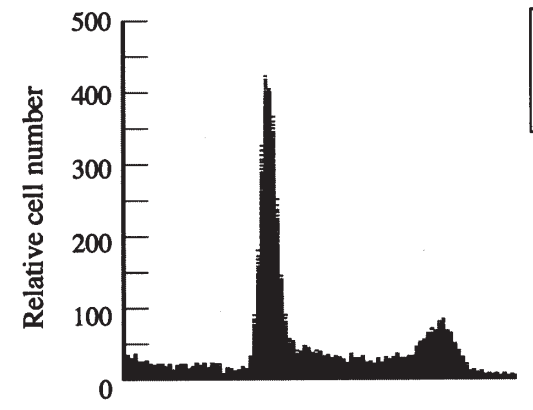

C

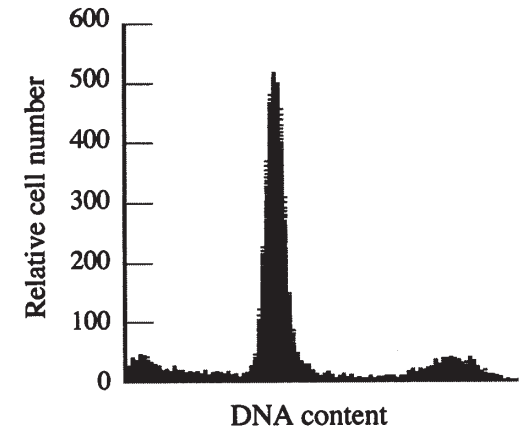

Figure 4. The effect of compound 5 on the cell cycle. HL-60 cells were incubated with $9.4 \mu \mathrm{M}$ compound 5 for $0 \mathrm{~h}(\mathrm{~A}), 12 \mathrm{~h}(\mathrm{~B})$ and $24 \mathrm{~h}(\mathrm{C})$. Cell cycle distribution was calculated as the percentage of cells in G1, S and $\mathrm{G} 2 / \mathrm{M}$ phases. All experiments were performed three times.

cycle analysis were more directly confirmed by the incorporation experiment. Fig. 5A-C shows the incorporation of $\left[{ }^{3} \mathrm{H}\right]$-labeled thymidine, $\left[{ }^{3} \mathrm{H}\right]$-uridine and $\left[{ }^{3} \mathrm{H}\right]$-leucine into HL-60 cells, respectively. Compound 5 inhibited only the incorporation of $\left[{ }^{3} \mathrm{H}\right]$-thymidine time-dependently into the cells. The $\left[{ }^{3} \mathrm{H}\right]$-thymidine incorporation was decreased by $41.8 \%$ of the control level in the presence of the $\mathrm{LD}_{50}$ value of compound 5 (i.e., $9.4 \mu \mathrm{M}$ ) for $12 \mathrm{~h}$ (Fig. 5A). Neither $\left[{ }^{3} \mathrm{H}\right]$-uridine nor $\left[{ }^{3} \mathrm{H}\right]$-leucine incorporation was affected by the compound (Fig. 5B and C). These observations indicated that compound 5 must inhibit cell growth by blocking the primary step in the replication of DNA. The effect of the compound on HL-60 cells in Figs. 4 and 5 would suggest that compound 5 is distributed in the nucleus, and the mechanism of its action might be the inhibition of replicative pols (i.e., pols $\alpha, \delta$ and $\varepsilon$ ) rather than topos; therefore, cell cycle regulation was induced by the inhibition of pol activity by compound 5 .

Effects of compound 5 on apoptosis in human cancer cells. To examine whether the decrease in cell numbers caused by compound 5 was due to apoptosis, DNA fragmentation was
$\mathbf{A}$

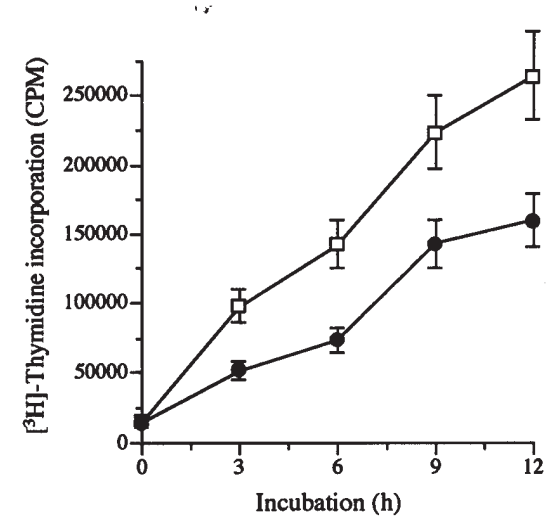

B

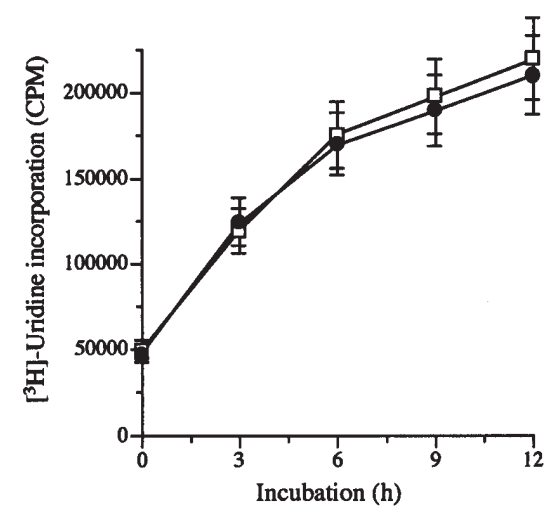

$\mathbf{C}$

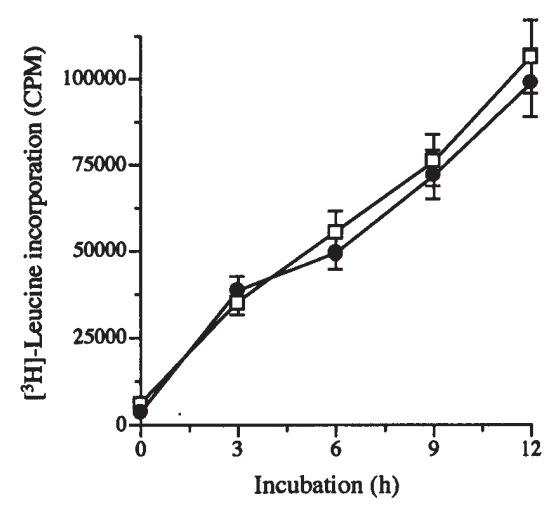

Figure 5. Measurement of DNA, RNA and protein synthesis in HL-60 cells incubated with compound 5. HL-60 cells $\left(1 \times 10^{4}\right)$ were incubated without (open square) or with $9.4 \mu \mathrm{M}$ compound 5 (control, closed circle) from $0 \mathrm{~h}$, and radiolabeled thymidine, uridine or leucine was added at $-0.5 \mathrm{~h}$. (A-C) Show the incorporation of radiolabeled thymidine, uridine and leucine, respectively. Each point represents the average of triplicate experiments and bars indicate SD.

analyzed by electrophoresis. A DNA ladder formation was dose-dependently observed in HL-60 cells treated with the $\mathrm{LD}_{50}$ value of the compound (i.e., $9.4 \mu \mathrm{M}$ ), and ladders were apparent at $6 \mathrm{~h}$ (Fig. 6). In cell cycle analysis, compound 5 -treated cells were in the sub-G1 phase (Fig. 4B and C). These results suggested that apoptotic effects were evident in the cells, and the effect of the compound must involve a combination of growth arrest and cell death. Compound 5 therefore should be considered the lead compound of potentially useful cancer chemotherapy agents. 


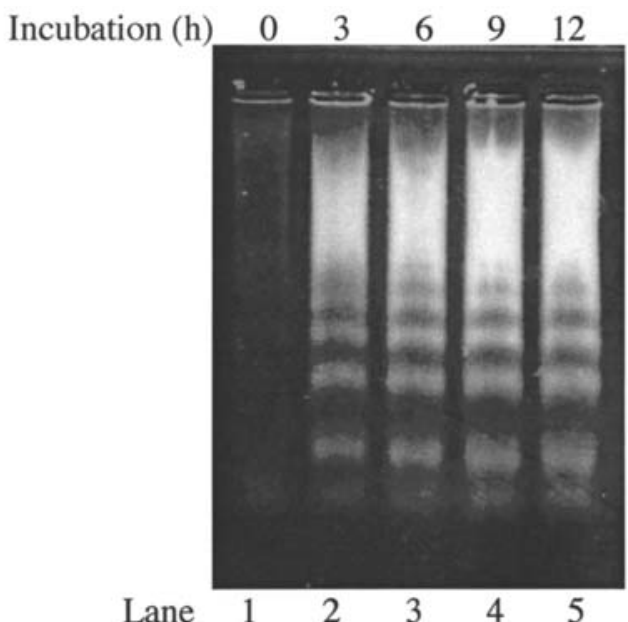

Figure 6. Detection of intracellular DNA ladder formation in HL-60 cells treated with $9.4 \mu \mathrm{M}$ compound 5 for $0 \mathrm{~h}$ (lane 1), $3 \mathrm{~h}$ (lane 2), $6 \mathrm{~h}$ (lane 3 ), $9 \mathrm{~h}$ (lane 4) and $12 \mathrm{~h}$ (lane 5). Following cell lysis, total DNA was extracted and analyzed by agarose gel electrophoresis

\section{Discussion}

As described in this report, we found that chemically synthesized acetogenins inhibited the activities of mammalian pols and human cancer cell growth. In particular, compound 5 showed the strongest inhibition in the tested acetogenins, and it was revealed that the inhibition of pol activity by compound 5, which is an inhibitor of mammalian pols and topos, influenced not only cell proliferation but also the cell cycle.

Most acetogenins exhibit potent and selective in vitro anti-tumor activities. For example, mucocin (compound 1) is reported to show remarkable inhibitory activities against A-549 (lung cancer) and PACA-2 (pancreatic cancer) solid tumor lines (49). As the mode of action, blockage of the mitochondrial NADH-ubiquinone oxidoreductase in complex I, which is a membrane-bound and essential enzyme for ATP production, is discussed (49). Furthermore, these natural products were also shown to inhibit a ubiquinonelinked NADH oxidase found in the plasma membrane of specific tumor cell lines, including some which show multidrug resistance (50). Very little research, however, has been pursued on the inhibition of acetogenins against pol and topo activities until now, probably due to the small quantities of natural products. Since the total synthesis of bioactive acetogenins such as compound 5 could be possible (16-24), these compounds should be provided and studied in pharmaceutical research throughout the world.

Compound 5 used in this study directly inhibited animal pols and human topos activities (Table I), but it did not bind to DNA (data not shown). These observations suggested that there may be some structural similarity between both enzymes at the compound 5-binding site, although the characteristics of both pols and topos, including their modes of action, amino acid sequences and three-dimensional structures, are markedly different. We previously reported that several inhibitors, long chain fatty acids $(37,38)$ and triterpenoids $(51,52)$, of mammalian pol $\beta$ could also inhibit topo II activity, and both enzymes have structural homology at the DNA-binding site (53-55), and the DNA-binding site of long chain fatty acids on the pol was the same domain (i.e., the N-terminal 8 -kDa domain of pol $\beta$ ) as that of triterpenoids $(53,56)$. Therefore, compound 5 was expected to have similar characteristics. Topos and pols have recently emerged as important cellular targets for chemical intervention in the development of anti-cancer agents; therefore, information concerning the structural characteristics of these inhibitors could provide valuable insight for the design of new anti-cancer agents.

\section{Acknowledgements}

This work was supported in part by a Grant-in-aid for Kobe-Gakuin University Joint Research (A), and 'Academic Frontier' Project for Private Universities: matching fund subsidy from the Ministry of Education, Science, Sports, and Culture of Japan (MEXT), 2006-2010, (Y.M. and H.Y.). Y.M. acknowledges a Grant-in-Aid for Young Scientists (A) (No. 19680031) from MEXT, and a Grant-in-aid from the Nakashima Foundation (Japan). Financial supports by a Grant-in-Aid for Scientific Research from MEXT, and by the Chemical Biology Research Program from RIKEN are greatly appreciated (S.T.).

\section{References}

1. Kornberg A and Baker TA: DNA replication. 2nd edition. W.D. Freeman and Co., New York, pp197-225, 1992.

2. Bebenek K and Kunkel TA: DNA repair and replication. In: Advances in Protein Chemistry. Yang W (ed). Elsevier, San Diego 69: 137-165, 2004.

3. Friedberg EC, Feaver WJ and Gerlach VL: The many faces of DNA polymerases: strategies for mutagenesis and for mutational avoidance. Proc Natl Acad Sci USA 97: 5681-5683, 2000.

4. Wang JC: DNA topoisomerases. Annu Rev Biochem 65: 635-692, 1996.

5. Chakraborty AK and Majumder HK: Mode of action of pentavalent antimonials: specific inhibition of type I DNA topoisomerase of Leishmania donovani. Biochem Biophys Res Commun 152: 605-611, 1988.

6. Liu LF: DNA topoisomerase poisons as antitumor drugs. Annu Rev Biochem 58: 351-375, 1989.

7. Ray S, Hazra B, Mittra B, Das A and Majumder HK: Diospyrin, a bisnaphthoquinone: a novel inhibitor of type I DNA topoisomerase of Leishmania donovani. Mol Pharmacol 54: 994-999, 1998.

8. Sakaguchi K, Sugawara F and Mizushina Y: Inhibitors of eukaryotic DNA polymerases. Seikagaku 74: 244-251, 2002.

9. Rupprecht JK, Hui YH and McLaughlin JL: Annonaceous acetogenins: (Review). J Nat Prod 53: 237-278, 1990.

10. Alali FQ, Liu XX and McLaughlin JL: Annonaceous acetogenins: recent progress. J Nat Prod 62: 504-540, 1999.

11. Berrnejo A, Figadere B, Zafra-Polo MC, Barrachina I, Estornell E and Cortes D: Acetogenins from annonaceae: recent progress in isolation, synthesis and mechanisms of action. Nat Prod Rep 22: 269-303, 2005.

12. Alali FQ, Rogers L, Zhang Y and McLaughlin JL: Unusual bioactive annonaceous acetogenins from Goniothalamus giganteus. Tetrahedron 54: 5833-5844, 1998.

13. Chavez D, Acevedo LA and Mata R: Jimenezin, a novel annonaceous acetogenin from the seeds of Rollinia mucosa containing adjacent tetrahydrofuran-tetrahydropyran ring system. J Nat Prod 61: 419-421, 1998.

14. Shi G, Alfonso D, Fatope MO, Zeng L, Gu ZM, Zhao GX, He K, MacDougal JM and McLaughlin JL: Mucocin: a new annonaceous acetogenin bearing a tetrahydropyran ring. J Am Chem Soc 117: 10409-10410, 1995.

15. Shi G, Kozlowski JF, Schwedler JT, Wood KV, MacDougal JM and McLaughlin JL: Muconin and mucoxin: additional nonclassical bioactive acetogenins from Rollinia mисоsa. J Org Chem 61: 7988-7989, 1996. 
16. Pupo MT, Vieira PC, Fernandes JB and Silva MFGF: $\gamma$-Lactones from Trichilia claussenii. Phytochemistry 48: 307-310, 1998.

17. Takahashi S and Nakata T: Total synthesis of an antitumor agent, mucocin, based on the 'chiron approach'. J Org Chem 67: 5739-5752, 2002.

18. Takahashi S, Kubota A and Nakata T: Stereoselective total synthesis of mucocin, an antitumor agent. Angew Chem Int Ed Engl 41: 4751-4754, 2002.

19. Takahashi S, Maeda K, Hirota S and Nakata T: Total synthesis of a new cytotoxic acetogenin, jimenezin and the revised structure. Org Lett 1: 2025-2028, 1999.

20. Takahashi S, Kubota A and Nakata T: Stereoselective total synthesis of muconin. Tetrahedron 59: 1627-1638, 2003.

21. Takahashi S, Kubota A and Nakata T: Total synthesis of a cytotoxic acetogenin, pyranicin. Org Lett 5: 1353-1356, 2003.

22. Takahashi S, Ogawa N, Koshino H and Nakata T: Total synthesis of the proposed structure for pyragonicin. Org Lett 7: 2783-2786, 2005.

23. Takahashi S, Hongo H, Ogawa N, Koshino H and Nakata T: Convergent synthesis of pyragonicin. J Org Chem 71: 6305-6308, 2006.

24. Takahashi S, Ogawa N, Sakairi N and Nakata T: Stereoselective synthesis of $(2 \mathrm{R}, 3 \mathrm{~S}, 4 \mathrm{~S})$-3-hydroxy-4-methyl-2-tetradecyl-4butanolide starting from 2,5-anhydro-D-mannitol. Tetrahedron 61: 6540-6545, 2005.

25. Tamai K, Kojima K, Hanaichi T, Masaki S, Suzuki M, Umekawa H and Yoshida S: Structural study of immunoaffinity-purified DNA polymerase $\alpha$-DNA primase complex from calf thymus. Biochim Biophys Acta 950: 263-273, 1988.

26. Date T, Yamaguchi M, Hirose F, Nishimoto Y, Tanihara K and Matsukage A: Expression of active rat DNA polymerase $\beta$ in Escherichia coli. Biochemistry 27: 2983-2990, 1988.

27. Umeda S, Muta T, Ohsato T, Takamatsu C, Hamasaki N and Kang D: The D-loop structure of human mtDNA is destabilized directly by 1 -methyl-4-phenylpyridinium ion (MPP+), a parkinsonism-causing toxin. Eur J Biochem 267: 200-206, 2000.

28. Oshige M, Takeuchi R, Ruike R, Kuroda K and Sakaguchi K: Subunit protein-affinity isolation of Drosophila DNA polymerase catalytic subunit. Protein Expr Purif 35: 248-256, 2004.

29. Masutani C, Kusumoto R, Iwai S and Hanaoka F: Mechanisms of accurate translesion synthesis by human DNA polymerase $\eta$. EMBO J 19: 3100-3109, 2000.

30. Tissier A, Frank EG, McDonald JP, Iwai S, Hanaoka F and Woodgate R: Misinsertion and bypass of thymine-thymine dimers by human DNA polymerase ı. EMBO J 19: 5259-5266, 2000.

31. Ohashi E, Ogi T, Kusumoto R, Iwai S, Masutani C, Hanaoka F and Ohmori $\mathrm{H}$ : Error-prone bypass of certain DNA lesions by the human DNA polymerase $\kappa$. Genes Dev 14: 1589-1594, 2000.

32. Shimazaki N, Yoshida K, Kobayashi T, Toji S, Tamai T and Koiwai O: Overexpression of human DNA polymerase lambda in $E$. coli and characterization of the recombinant enzyme. Genes Cells 7: 639-651,2002.

33. Yamaguchi T, Saneyoshi M, Takahashi H, Hirokawa S, Amano R, Liu X, Inomata M and Maruyama T: Synthetic nucleoside and nucleotides. 43. Inhibition of vertebrate telomerases by carbo-cyclic oxetanocin G (C.OXT-G) triphosphate analogues and influence of C.OXT-G treatment on telomere length in human HL60 cells. Nucleos Nucleot Nucleic Acids 25: 539-551, 2006

34. Aoyagi N, Matsuoka S, Furunobu A, Matsukage A and Sakaguchi K: Drosophila DNA polymerase $\delta$ : purification and characterization. J Biol Chem 269: 6045-6050, 1994.

35. Aoyagi N, Oshige M, Hirose F, Kuroda K, Matsukage A and Sakaguchi K: DNA polymerase $\varepsilon$ from Drosophila melanogaster. Biochem Biophys Res Commun 230: 297-301, 1997.

36. Sakaguchi K, Hotta Y and Stern H: Chromatin-associated DNA polymerase activity in meiotic cells of lily and mouse. Cell Struct Funct 5: 323-334, 1980.

37. Mizushina Y, Tanaka N, Yagi H, Kurosawa T, Onoue M, Seto H, Horie T, Aoyagi N, Yamaoka M, Matsukage A, Yoshida S and Sakaguchi K: Fatty acids selectively inhibit eukaryotic DNA polymerase activities in vitro. Biochim Biophys Acta 1308: 256-262, 1996
38. Mizushina Y, Yoshida S, Matsukage A and Sakaguchi K The inhibitory action of fatty acids on DNA polymerase $B$. Biochim Biophys Acta 1336: 509-521, 1997.

39. Ogawa A, Murate T, Suzuki M, Nimura Y and Yoshida S: Lithocholic acid, a putative tumor promoter, inhibits mammalian DNA polymerase B. Jpn J Cancer Res 89: 1154-1159, 1998.

40. Tamiya-Koizumi K, Murate T, Suzuki M, Simbulan CG, Nakagawa M, Takamura M, Furuta K, Izuta S and Yoshida S: Inhibition of DNA primase by sphingosine and its analogues parallels with their growth suppression of cultured human leukemic cells. Biochem Mol Biol Int 41: 1179-1189, 1997.

41. Nakayama $C$ and Saneyoshi M: Inhibitory effects of 9-B-Dxylofuranosyladenine 5'-triphosphate on DNA-dependent RNA polymerase I and II from cherry salmon (Oncorhynchus masou). J Biochem 97: 1385-1389, 1985.

42. Spitzner JR, Chung IK and Muller MT: Eukaryotic topoisomerase II preferentially cleaves alternating purine-pyrimidine repeats. Nucleic Acids Res 18: 1-11, 1990.

43. Soltis DA and Uhlenbeck OC: Isolation and characterization of two mutant forms of T4 polynucleotide kinase. J Biol Chem 257: 11332-11339, 1982.

44. Lu BC and Sakaguchi K: An endo-exonuclease from meiotic tissues of the basidiomycete Coprinus cinereus: its purification and characterization. J Biol Chem 266: 21060-21066, 1991.

45. Mosmann T: Rapid colorimetric assay for cellular growth and survival: application to proliferation and cytotoxicity assays. J Immunol Methods 65: 55-63, 1983.

46. Sambrook J, Fritsch EF and Maniatis T: Molecular Cloning, a Laboratory Manual. 2nd edition. Cold Spring Harbor Laboratory Press, Cold Spring Harbor, NY, 1989.

47. Murakami-Nakai C, Maeda N, Yonezawa Y, Kuriyama I, Kamisuki S, Takahashi S, Sugawara F, Yoshida H, Sakaguchi K and Mizushina Y: The effects of dehydroaltenusin, a novel mammalian DNA polymerase $\alpha$ inhibitor, on cell proliferation and cell cycle progression. Biochim Biophys Acta 1674: 193-139, 2004.

48. Nishida K, Seto M and Ishida R: Different susceptibilities of postmitotic checkpoint-proficient and -deficient Balb/3T3 cells to ICRF-193, a catalytic inhibitor of DNA topoisomerase II. Jpn J Cancer Res 92: 193-202, 2001.

49. Degli Esposti M: Inhibitors of NADH-ubiquinone reductase: an overview. Biochim Biophys Acta 1364: 222-235, 1998.

50. Oberlies NH, Chang CJ and McLaughlin JL: Structure-activity relationships of diverse annonaceous acetogenins against multidrug resistant human mammary adenocarcinoma (MCF-7/Adr) cells. J Med Chem 40: 2102-2106, 1997

51. Mizushina Y, Tanaka N, Kitamura A, Tamai K, Ikeda M, Takemura M, Sugawara F, Arai T, Matsukage A, Yoshida S and Sakaguchi K: The inhibitory effect of novel triterpenoid compounds, fomitellic acids, on DNA polymerase B. Biochem J 330: 1325-1332, 1998.

52. Tanaka N, Kitamura A, Mizushina Y, Sugawara F and Sakaguchi K: Fomitellic acids, triterpenoid inhibitors of eukaryotic DNA polymerases from a basidiomycete, Fomitella fraxinea. J Nat Prod 61: 193-197, 1998.

53. Mizushina Y, Ohkubo T, Date T, Yamaguchi T, Saneyoshi M, Sugawara F and Sakaguchi K: Mode analysis of a fatty acid molecule binding to the N-terminal 8-kDa domain of DNA polymerase B. J Biol Chem 274: 25599-25607, 1999.

54. Mizushina Y, Sugawara F, Iida A and Sakaguchi K: Structural homology between DNA binding sites of DNA polymerase $B$ and DNA topoisomerase II. J Mol Biol 304: 385-395, 2000.

55. Mizushina Y, Iida A, Ohta K, Sugawara F and Sakaguchi K: Novel triterpenoids inhibit both DNA polymerase and DNA topoisomerase. Biochem J 350: 757-763, 2000.

56. Mizushina Y, Ohkubo T, Sugawara F and Sakaguchi K: Structure of lithocholic acid binding to the N-terminal 8-kDa domain of DNA polymerase B. Biochemistry 39: 12606-12613, 2000 . 